\section{PÄÄKIRJOITUS}

ERJA POUTIAINEN

\title{
KUNTOUTUS-LEHTI JATKAA VANKALLA TIETEELLIS-AMMATILLISELLA LINJALLA - DIGITAALISESTI
}

Tutkittua tietoa on tärkeää tuottaa ja levittää kansainvälisten julkaisujen lisäksi kotimaisilla areenoilla. Oma merkityksensä on myös sillä, että tutkimustuloksia julkaistaan ja niistä keskustellaan sillä kielellä, jolla ne on tehty, ja siinä maassa, jonka väestöä, rakenteita ja järjestelmiä ne koskevat. Tutkitun tiedon välittäminen toisille tutkijoille, ammattilaisille, päättäjille ja kansalaisille yhteiskunnan omassa kontekstissa on merkityksellistä. Kotimainen julkaisu on niin ikään hyvä paikka keskustella eri aloilta tulevien tutkijoiden ja ammattilaisten kanssa. Tällä tavalla on helpompaa löytää yhteinen kieli, jolla monitieteellisestä ja moniammatillisesta kuntoutuksestakin päästään yhdessä keskustelemaan. Yhteinen keskustelu on tiedemaailman avoimuudelle tärkeää.

Avoin julkaiseminen on tieteen yhteinen tavoite. Tieteellisten seurain valtuuskunta (TSV), jolta toinen lehden julkaisija Kutke ry saa avustusta Kuntoutus-lehden julkaisemiseen, on vahvasti mukana edistämässä avointa julkaisemista, jotta tieteellinen tieto olisi kaikkien kiinnostuneiden käytössä. Avoimen julkaisemisen edistämiseksi TSV tarjoaa lehdille sähköisen OJS-julkaisualustan (Open Journal System). Sen puitteissa toimiva Journal.fi-sivusto on tiedelehtien toimittamiseen ja julkaisemiseen tarkoitettu palvelu. Sivustolla oli elokuussa 2020 yli 90 suomalaista tieteellistä lehteä ja vuosikirjaa, ja nyt myös Kuntoutus-lehti liittyy tähän joukkoon. Avoimen julkaisemisen periaatetta Kuntoutus-lehti toteuttaa avaamalla entiseen tapaansa artikkelinsa kaikille avoimeksi 12 kuukauden kuluttua niiden ilmestymisestä. Välittömästi avoimeen julkaisemiseen lehdellä ei valitettavasti ole tällä hetkellä taloudellisesti mahdollisuuksia, sillä lehti on riippuvainen tilaajamaksuistaan, joilla katetaan pääosa Kuntoutus-lehden kustannuksista.

Ensi vuonna vietetään tutkitun tiedon teemavuotta. Kyse on kansallisesta hankkeesta, jonka toteuttaa opetus- ja kulttuuriministeriö yhdessä Suomen Akatemian ja TSV:n kanssa. Sen puitteissa tullaan järjestämään erilaisia tilaisuuksia, tempauksia, toimia ja näyttelyitä, teoksia, interventioita sekä kehitysprojekteja ja kampanjoita, joko verkossa tai paikan päällä. Tavoitteena on lisätä tutkitun tiedon saavutettavuutta sekä näkyvyyttä paikallisesti ja valtakunnallisesti. Kannattaa seurata teemavuotta ja jakaa teemavuoden viestiä Twitterissä: @tttv2021(link is external), \#tttv21, \#tutkituntiedonteemavuosi.

Tässä vuoden viimeisen numeron tutkimusartikkeleissa kuntoutuk- 
sen tutkimuksen monitieteellisyys tulee hyvin esiin. Toinen artikkeli tarkastelee kuntoutuksen järjestämistä rekisteritutkimuksen avulla. Tulosten mukaan lähes viidesosa tarkastelun kohteena olevan kaupungin asukkaista käyttää kuntoutuspalveluja ja käyttö kasvaa iän myötä. Tyypillisimmin on saatu yhden osajärjestelmän piiriin kuuluvaa kuntoutusta. Tutkimus toi esiin yleisessä keskustelussakin usein mainitut kuntoutuksen kirjaamiskäytäntöjen puutteet sekä kuntoutusjärjestelmien hajanaisuuden ja siihen liittyvät useat rekisterinpitäjät. Toinen tieteellinen artikkeli kuuluu laadullisen tutkimuksen piiriin. Siinä käsitellään ryhmähaastattelulla kerättyä tietoa miesten hyvinvointiin liittyvän avun hakemisesta tai hakematta jättämisestä. Tutkimuksen mukaan miesten näkemykset avun hakemisesta ovat vuosien varrella muuttuneet. Lisäksi saamme lukea puheenvuoron pilottihankkeesta, jossa on tutkimuksen keinoin onnistuneesti pureuduttu kommunikaation apuvälineiden alueelliseen kehittämiseen ja palveluiden tarkoituksenmukaiseen porrastamiseen erikoissairaanhoidon ja perusterveydenhoidon välillä.

Kuntoutukseen liittyvä tutkimus on vireää, mitä osoittavat myös useat viimeaikaiset väitöstyöt, joissa kuntoutus on ollut joko suoraan tutkimuksen pääkohteena tai kuntoutukseen ja kuntoutumiseen liittyviä tekijöitä on tarkasteltu osana tutkimusta. Tässä lehdessä kolme tämän syyskauden aikana eri tieteenaloilta väitellyttä tutkijaa kuvaa väitöstutkimustaan ja päätuloksiaan. Saamme lukea työikäisinä aivoverenkiertohäiriön sairastaneiden kognitiivisesta kuntoutumisesta, MS-tautia sairastavien monialaisen ryhmäkuntoutuksen toimivuudesta sekä lasten ja perheiden sopeutumisvalmennuskurssien koetuista hyödyistä ja siitä, mitkä tekijät vaikuttavat osallistujien arviointeihin.

Ensi vuonna tutkitun tiedon äärelle pääsee myös muulla tavoin. Esimerkiksi 18.3.2021 kuntoutuksen tutkimuksesta kiinnostuneet voivat seurata hienoja kutsuesitelmiä ja tutkimusselostuksia kuntoutuksen tutkimuksen seminaarissa, jonka yleisteemana on 'Kuntoutus työelämän käännekohdassa'. Vielä ehtii myös tarjota seminaariin omaa tutkimusesitelmää tai -posteria, abstraktin viimeinen jättöpäivä on 7.1.2021.

Kuntoutus-lehti ilmestyy vuoden 2021 alusta alkaen yksinomaan verkkomuotoisena julkaisuna. Lehden tilaajat pääsevät maksukoodin saatuaan lukemaan verkkolehteä Journal.fi-sivustolla (https://journal.fi/kuntoutus). Sieltä löytyy painetun lehden kaltainen sähköinen versio, ja lisäksi oman kiinnostuksen mukaan voi avata artikkelit ja muut verkkolehden osiot yksittäin. Arkistoa kartutetaan aiemmilla numeroilla, jolloin vanhat julkaisut saadaan pysyvästi kaikkien ulottuville. Sisällöllisesti Kuntoutus-lehti jatkaa entiseen tapaansa tärkeiden kuntoutuksen tutkimusten ja tieteellis-ammatillisten katsausten, hanke-esittelyjen, puheenvuorojen, lectio praecursorioiden sekä Kuntoutuksessa tapahtuu -palstan julkaisemista Journal.fi-sivustolla. Lisäksi lehti julkaisee kuntoutuksen ajankohtaisiin aiheisiin liittyviä teemanumeroita. Vuoden 2021 teemanumeron aiheena on 'Kuntoutus työllisyysasteen nostajana', ja vuoden 2022 teemanumero tulee keskittymään nuorten kuntoutuksen ja tuen aihepiireihin.

\section{Rauhallista vuodenvaihdetta lukijoille toivottaen,}

\section{Erja Poutiainen}

Päätoimittaja, Kuntoutussäätiö 